\title{
Analisis Faktor-Faktor Sustainabilitas Lembaga Keuangan Mikro Syariah
}

\author{
Muhammad Kamal Zubair \\ Prodi Ekonomi Islam, STAIN Parepare \\ kamalzet@gmail.com
}

\begin{abstract}
Abstrak
Tulisan ini membahas faktor-faktor yang menjadi penentu keberlanjutan lembaga Baitul Mal wat Tamwil (BMT) sebagai Lembaga Keuangan Mikro Syariah (LKMS). Model yang dibangun melalui penelitian ini menunjukan bahwa variabelvariabel penyusun faktor eksternal, yaitu regulasi, pengawasan dan infrastruktur terbukti positif signifikan mempengaruhi sustainabilitas BMT, sedangkan variabel penyusun faktor internal, dari lima variabel yang diteliti, yaitu sumber daya manusia, manajemen, permodalan, jangkauan pasar dan inovasi produk, hanya dua variabel yang positif signifikan mempengaruhi sustainabilitas BMT, yaitu sumber daya manusia dan permodalan. Aspek-aspek tersebut dapat dijadikan sebagai tuntunan untuk meningkatkan kinerja BMT menuju sustainabilitas lembaga keuangan mikro syariah. Hasil penelitian ini lebih lanjut dapat dimanfaatkan untuk merancang kebijakan-kebijakan yang diperlukan untuk mendorong pengembangan BMT sehingga secara luas dan berkelanjutan mampu menjangkau dan memberdayakan pelaku usaha mikro.
\end{abstract}

Kata Kunci: Faktor, Sustainabilitas, BMT

\section{Abstract}

This paper discusses the factors that determine the sustainability

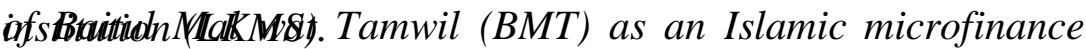
Models built through this study showed that shuperanisibhes naklinginfipathe external factors, namely regulation, tructure, proved to be positively 
significant to affect sustainability of BMT, while for the internal factors, only two of the five variables studied (human resources, management, capital, market range, and product innovation) were significantly and positively affecting the sustainability of $B M T$, namely human resources and capital. These aspects serve as a guide to improve the performance of BMT towards sustainability Islamic microfinance institutions through acceleration independent regulation of the BMT, to optimize the role and functions of supervision Sharia Supervisory Board (DPS) BMT, development of institutional infrastructure BMT, increasing the capacity of the human resources manager of BMT and strengthening capital resources BMT. Further results of this study can be utilized to design the necessary policies, to encourage the development of BMT, so that sustainability of $B M T$ can be widespread and reach as well as empower micro business.

Keywords: Factor, Sustainability, BMT

\section{PENDAHULUAN}

Kegiatan perekonomian di Indonesia, terutama sektor keuangan sangat didukung oleh lembaga-lembaga keuangan. Lembaga keuangan merupakan sektor yang paling besar pengaruhnya dalam aktifitas ekonomi masyarakat modern. Usaha mikro merupakan salah satu sektor yang memiliki peranan penting dalam perekonomian, namun selama ini sektor ini sulit berkembang, disebabkan karena pengusaha mikro yang umumnya berasal dari masyarakat lapisan bawah nyaris tidak tersentuh (undeserved) dan dianggap tidak memiliki potensi dana oleh lembaga keuangan formal terutama lembaga keuangan konvensional, sehingga menyebabkan laju perkembangannya terhambat. Keterbatasan akses sumber-sumber pembiayaan yang dihadapi oleh Usaha Mikro Kecil Menengah (UMKM) kepada perbankan, menyebabkannya tergantung pada sumber-sumber informal dan Lembaga Keuangan Mikro (LKM). LKM adalah lembaga yang memberikan jasa keuangan bagi pengusaha mikro dan masyarakat berpenghasilan rendah, baik formal, semi formal dan informal (Thohari, 2003). 
Berdasarkan deklarasi PBB mengenai tahun lembaga keuangan mikro pada tahun 2005 (international year of microfinance) sangat disarankan merealisasikan agenda penelitian mengenai keberlanjutan (sustainability) LKM. (Jiwani dan Husain 2011). Beberapa studi tentang LKM difokuskan pada penilaian kinerja dan sustainabilitas LKM dengan mengevaluasi indikator-indikator keuangan yang secara langsung mempengaruhi tingkat kemandirian, jangkauan dan mekanisme pemberian kredit. Hasil temuan Chaves dan Vega mengungkapkan bahwa keberhasilan LKM di Indonesia adalah sebagai akibat dari rancangan organisasi tersebut. Mereka berpendapat bahwa rancangan dari suatu organisasi yang akan menjadi perantara layanan keuangan sangatlah penting karena hal tersebut akan menentukan kinerja LKM tersebut dan pada akhirnya menentukan keberhasilan kegagalannya (Chaves dan Vega, 1996).

Salah satu model LKM yang dalam satu dasawarsa ini berkembang relatif pesat di Indonesia adalah LKM Syariah. Kegiatan Lembaga Keuangan Mikro Syariah (LKMS) secara prinsip hampir sama dengan LKM konvensional, namun ada beberapa perbedaan dalam hal akad dan transaksinya, yaitu dengan sistem syariah yang tidak memperkenankan adanya bunga. Melalui sistem syariah ini dikembangkan bentuk-bentuk pembiayaan untuk usaha kecil dengan menggunakan sistem profit sharing.

Lembaga keuangan mikro syariah dijelaskan sebagai suatu sistem keuangan berbasis Islam atau yang dikenal dengan syariah. LKMS yang dimaksudkan disini adalah Baitul Mal wat Tamwil (BMT). Secara kuantitatif, lembaga ini mengalami perkembangan yang sangat pesat. Perkembangan BMT yang pesat ini terjadi karena tingginya kebutuhan masyarakat akan jasa intermediasi keuangan, tetapi di sisi lain akses ke dunia perbankan yang lebih formal relatif sulit. BMT memberikan solusi bagi masyarakat untuk mendapatkan dana dengan mudah dan cepat, terhindar dari jerat rentenir, dan mengacu pada prinsip syariah. LKMS terbilang mengalami perkembangan paling menonjol selama lima belas tahun terakhir, jika dibandingkan dengan berbagai lembaga keuangan syariah lainnya di Indonesia. 
Peran sebagai lembaga keuangan yang mendukung fungsi intermediasi dengan UMKM menuntut BMT memiliki kinerja yang baik secara kelembagaan agar tujuan memerankan BMT sebagai lembaga pendukung fungsi intermediasi perbankan akan tercapai dengan baik. (Amaliah, 2009). Namun demikian, BMT sejauh ini dipandang belum sepenuhnya mampu menjawab permasalahan ekonomi yang ada dikalangan masyarakat, karena masalah sumber daya manusia (SDM) yang belum profesional, modal dan tingkat kepercayaan yang rendah dari masyarakat, dan infrastuktur yang terbatas serta belum adanya rumusan flatform untuk mengembangkan LKMS tersebut. Saat ini kalangan BMT menghadapi beberapa persoalan bersifat internal maupun eksternal yang menghambat proses menuju kemandirian. Selain itu, BMT masih belum memiliki payung hukum ataupun legalitas dan perundangundangan yang mengatur standar operasional dan prosedur yang jelas. Terdapat kerumitan peraturan yang mengikat BMT dan kerumitan tersebut menjadi hambatan bagi perkembangan BMT karena kurangnya pengawasan dan pelaporan (Sakai dan Marijan, 2008).

Di sisi lain, kapasitas BMT merupakan salah satu model lembaga keuangan syariah yang paling sederhana. Oleh karena itu, sektor BMT di Indonesia sangat berpotensi untuk dikembangkan lebih jauh jika BMT mampu mengatasi kelemahan-kelemahan dalam operasionalnya. BMT dalam menjalankan usahanya harus memperoleh keuntungan agar aktivitasnya dapat berlanjut (sustainable) dan kemampuan melayani nasabah semakin meningkat (outreach).

Dengan memperhatikan dan menimbang nilai strategis BMT sebagai LKMS, maka kajian ini akan menguji faktorfaktor internal dan eksternal yang mempengaruhi sustainabilitas BMT sebagai lembaga mikro yang berbasis syariah. Tujuan dari penelitian ini adalah untuk mengidentifikasi secara cermat faktor-faktor internal dan faktor-faktor eksternal yang mempengaruhi sustainabilitas BMT, kemudian menguji faktorfaktor internal dan eksternal yang mempengaruhi sustainabilitas BMT sebagai lembaga mikro yang berbasis syariah. 


\section{KAJIAN LITERATUR}

Penelitian The Asia Foundation dengan judul Microfinance Service in Indonesia : Survey of Institutions in 6 Provinces mengkaji lembaga keuangan bank dan lembaga non bank, termasuk BMT yang ada di daerah Bandung, Madiun, Pontianak, Samarinda, Manado dan Jayapura. Fokus kajian diantaranya adalah mengevaluasi kapabilitas lembaga keuangan mikro di sejumlah wilayah di Indonesia. Kapabilitas yang dimaksud dalam kajian ini meliputi efisiensi, sustainability dan ability, terutama kemampuan dalam pengembangan jaringan pelayanan dan kemampuan lembaga keuangan mikro dalam mengembangkan jaringan kelembagaan yang luas (The Asia Fondation, 2003).

Promotion of Small Financial Institution (ProFi) mengungkapkan bahwa sistem keuangan mikro di Indonesia saat ini memiliki masalah-masalah antara lain: 1) jangkauan; 2) rerangka legal; hanya ada dua jenis LKM yaitu BPR dan koperasi yang diakui secara legal; 3) regulasi dan supervisi: ketiadaan regulasi dan supervisi bagi LKM yang bukan BPR maupun koperasi; 4) struktur dukungan: ketiadaan rerangka legal yang cukup mengakibatkan tidak ada pihak yang merasa bertanggung jawab dalam hal regulasi, supervisi, dan dukungan terhadap LKM selain BPR dan koperasi (ProFI, 2005).

Hasil penelitian Campion menyimpulkan bahwa komersialisasi industri keuangan mikro menghadapi beberapa hambatan yaitu: 1) subsidi yang tidak tepat; 2) regulasi dan pengawasan yang buruk; 3) hanya sedikit LKM yang mampu mengumpulkan tabungan dari masyarakat; 4) kapasitas manajemen yang terbatas; 5) belum efisien secara kelembagaan; 6) memerlukan penguasaan metode keuangan mikro yang lebih baik untuk daerah perdesaan dan sektor pertanian. (Campion, 2002). Keadaan ini menyebabkan tingkat keberlanjutan usaha atau sustainability LKM maupun program keuangan mikro menjadi rendah. Hanya beberapa LKM yang mampu bertahan dan bersaing baik dengan sesama LKM maupun jenis layanan perbankan yang lebih modern.

Secara umum para ahli mengkaji sustainabilitas dengan dua pendekatan, yaitu pendekatan kesejahteraan dan pendekatan kelembagaan. Menurut Murdoch, dalam gerakan keuangan 
mikro (microfinance movement) di dunia dalam hal menjangkau kaum miskin melalui pemberian akses terhadap layanan keuangan, terdapat dua pendekatan utama yaitu pendekatan kelembagaan (institutionist approach) dan pendekatan kesejahteraan (welfarist approach). Penelitian menunjukkan bahwa lembaga keuangan mikro secara signifikan ditandai dengan pendekatan institusional untuk keberlanjutan (Murdock, 2000).

Pendekatan kelembagaan fokus pada penciptaan lembaga keuangan untuk menjangkau nasabah yang tak terlayani oleh sistem keuangan formal. Penekanan terhadap kelembagaan terdapat pada pencapaian kecukupan keuangan (financial self sufficiency), lebar jangkauan (breadth of outreach) yang artinya jumlah nasabah terlayani, serta dampaknya secara positif terhadap nasabah (positive client impact). Sementara pendekatan kesejahteraan lebih menekankan pada kedalaman jangkauan (depth of outreach) yang berarti level masyarakat termiskin yang dilayani. Pendekatan ini tidak selalu melihat sisi kelembagaan, tapi penekanan pada dampak (impact) dari layanan keuangan terhadap masyarakat miskin yang aktif secara ekonomi (economically active poor).

Dalam pelaksanaannya, Robinson mencatat bahwa kedua pendekatan tersebut pada dasarnya mempunyai peran yang sama dalam pengembangan keuangan mikro institusional. Kunci bagi keberlanjutan (sustainability) dari sebuah LKM adalah keharusan dari adanya tujuan komersil (profit making objective) yakni kemampuan menghasilkan laba, disamping adanya misi sosial yang diemban (social mission). Penyelenggaraan jasa keuangan mikro yang sustainable dapat dilaksanakan oleh institusi komersial yang memberikan layanan keuangan kepada masyarakat miskin yang aktif secara ekonomi. Aspek terpenting adalah menyediakan layanan kredit dan tabungan secara menguntungkan dan dapat menjangkau nasabah dalam skala besar. Hal ini dimungkinkan apabila LKM telah diregulasi dan mandiri (Robinson, 2001).

Menurut Association for Social Advancement (ASA), sustainabilitas LKM dapat dilihat dari aspek sustainabilitas lembaga dan sustainabilitas keuangan. Sustainabilitas lembaga adalah kemampuan LKM untuk beroperasi secara berkelanjutan yang didukung oleh faktor keberhasilan dalam 
mengimplementasikan cost-effectiveness sebagai kunci utama kegiatan usahanya, sedangkan sustainabilitas keuangan merupakan kondisi keuangan suatu LKM yang dalam kegiatannya dapat mencukupi kebutuhan biaya operasi dan biaya dana untuk jangka panjang (Meyer, 2002).

Asian Development Bank (ADB) melakukan kajian tentang pengembangan LKM. Menurut ADB, infrastruktur keuangan merupakan hal yang menentukan sustainabilitas, yang terdiri dari tata hukum untuk transaksi keuangan dan daya paksa (law enforcement) terhadap sebuah kontrak perjanjian. Tata hukum transaksi lembaga keuangan meliputi regulasi dengan prinsip kehati-hatian, pengawasan terhadap lembaga keuangan, keterbukaan informasi keuangan, kebijakan dan praktek akuntansi, serta fasilitas pelatihan untuk akuntan. Di sisi lain, kapasitas kelembagaan mencakup kemampuan untuk mengurangi biaya-biaya transaksi, mencapai tingkatan untuk terus bertahan hidup dan mencapai jangkauan yang lebih luas. Sustainabilitas dan kapasitas LKM ditentukan oleh kemampuannya beroperasi secara komersial (ADB, 2000).

Teori sustainabilitas LKM yang dikembangkan selama ini menyatakan bahwa sustainabilitas LKM adalah kemampuan LKM dalam menjalankan sistem yang telah dibangun agar dapat beroperasi secara berkelanjutan. Begitupun LKM yang memiliki kemampuan sebagai penyedia keuangan mikro untuk menutupi semua biaya dalam mencapai financial sustainability. Sistem tersebut dalam konsep sustainabilitas LKM syariah diukur berdasarkan pada syariah compliance finance yang merujuk pada pendapatan yang cukup untuk menutupi biaya modal dan biaya pendanaan. Pendapatan dan biaya modal dalam LKM syariah diperoleh bukan dari transaksi ribawi, tadlis, perilaku spekulasi, perjudian dan gharar. Sustainabilitas LKM merupakan kemampuan LKM untuk bertahan, secara terus menerus dalam menutupi biaya operasional dengan menggunakan pendapatan usaha yang dihasilkan dari aktifitas bisnis (Woller et. al,. 1991).

Berdasarkan Rapat Kerja Nasional (Rakernas) Pusat Inkubasi Bisnis Usaha Kecil (Pinbuk) tahun 2009 telah disepakati sebuah konsep Arsitektur Baitul Mal wat Tamwil Indonesia (ABI) yang merupakan salah satu faktor penting untuk mendorong perkembangan bisnis keuangan mikro syariah. 
Arsitektur BMT Indonesia ini mencakup lima program. Kelima program tersebut adalah program perkuatan struktur BMT nasional, program peningkatan fungsi pengawasan BMT, program peningkatan kualitas manajemen dan operasional BMT, program pengembangan infrastruktur BMT, dan program perlindungan nasabah BMT. Dalam rangka implementasi ABI tersebut maka dirumuskan 7 Pilar Arsitektur BMT di Indonesia, yaitu : 1) Perkuatan Kelembagaan BMT, 2) Peningkatan Kualitas Tata Kelola BMT, 3) Peningkatan Fungsi Pengawasan BMT, 4) Peningkatan Kualitas Manajemen dan Operasional BMT, 5) Pengembangan Infrastruktur BMT, 6) Peningkatan Perlindungan Anggota BMT, 7) Peningkatan dan Pengembangan Social Insurance.

Dengan mengacu pada pilar-pilar tersebut dan berdasarkan uraian tentang teori sustainabilitas lembaga keuangan mikro (LKM) dan penelitian sebelumnya, maka dapat dirumuskan faktor-faktor eksternal dan internal yang terindikasi mempengaruhi sustainabilitas BMT. Faktor eksternal meliputi tiga aspek, yaitu aspek regulasi, aspek pengawasan, dan aspek infrastruktur, sedangkan faktor internal terdiri dari lima aspek, yaitu aspek sumber daya manusia (SDM), aspek manajemen, aspek permodalan, aspek jangkauan pasar, dan aspek inovasi produk.

Perkembangan BMT yang kian pesat membutuhkan regulasi dan pengawasan yang mengatur segala aspek yang menyangkut operasional BMT. Sustainabilitas operasional LKM dalam jangka panjang sangat ditentukan oleh tersedianya kerangka regulasi dan pengawasan yang sehat dan efektif. Hal ini diperkuat oleh hasil penelitian Bank Indonesia. (Bank Indonesia, 2001) Alasan utama perlunya regulasi dan pengawasan terhadap LKM adalah informasi yang assimetris diantara faktor yang terlibat dalam operasional LKM. Regulasi dan pengawasan diperlukan untuk memastikan bahwa operasional BMT dapat berjalan baik sehingga akan akan menguntungkan bagi lembaga keuangan maupun nasabah. Regulasi dengan prinsip kehati-hatian diperlukan untuk melindungi sistem keuangan dari kemungkinan terjadinya resiko sistematik.

Mengingat kegiatan BMT berkaitan erat dengan dana dari masyarakat atas dasar kepercayaan, maka setiap pelaku 
BMT diharapkan tetap menjaga kepercayaan tersebut. Kepercayaan masyarakat terhadap lembaga keuangan mikro syariah ini akan terjaga apabila BMT diselenggarakan dan dikelola dengan prinsip kehati-hatian sehingga selalu terpelihara kondisi kesehatannya. Atas dasar itu, BMT harus diatur dan diawasi dengan ketat. Pentingnya pengawasan terutama untuk melindungi nasabah dan menghindari moral hazard sebagai akibat adanya perbedaan kepentingan antara lembaga dan nasabah. Oleh karena itu, pengawasan yang efektif membutuhkan adanya pengawas dengan kompetensi khusus karena aspek-aspek yang diawasi sangat spesifik dan rinci. Pengawasan terhadap BMT dapat berjalan efektif apabila dilakukan secara internal dan eksternal. Pengawasan eksternal dilakukan melalui pembentukan atau penunjukan suatu lembaga eksternal yang independen untuk menilai tingkat kesehatan BMT. Sedangkan pengawasan internal dilakukan oleh Dewan Pengawas Syariah (DPS).

Kegiatan usaha BMT dapat berjalan berkelanjutan apabila didukung oleh infrastruktur kelembagaan yang kuat sebagai penunjang pemberdayaan BMT. Dengan dukungan infrastruktur kelembagaan yang memadai terhadap aktivitas keuangan mikro terbukti mampu menumbuhkan industri tersebut secara sehat. Hal ini diperkuat oleh penelitian ADB bahwa pemerintah seharusnya mengubah pola intervensi secara langsung menjadi intervensi secara tidak langsung dengan membangun infrastruktur pendukung yang diperlukan oleh lembaga keuangan mikro.

BMT adalah lembaga kepercayaan sehingga sumber daya manusia merupakan aset utama yang harus mempunyai integritas dan kompetensi. Sumber daya manusia ini harus mampu mengelola BMT secara transparan dan akuntabel dengan suatu sistem manajemen operasional yang baik. Aspek SDM sangat terkait dengan tingkat pendidikan. Bagaimanapun tingkat pendidikan merupakan faktor penting yang mampu membentuk skill kepengurusan seseorang. Hal ini diperkuat dengan hasil penelitian Akhyar bahwa kinerja BMT dipengaruhi oleh kemampuan manajemen dan pengelola BMT. (Adnan et. al., 2003).

Dengan mengacu pada penilaian tingkat kesehatan BMT, dapat diketahui bahwa unsur utama dari sustainabilitas adalah 
tata kelola yang baik dan kualitas manajemen dan operasional. Tata kelola atau manajemen operasi diukur dengan suatu indikator penerapan standar operasional dan prosedur (SOP) dan standar operasional manajemen (SOM). Dengan penerapan SOP dan SOM maka operasionalisasi lembaga akan berdasarkan suatu sistem yang baku, sehingga terjamin adanya transparansi dan akuntabilitas dalam pengelolaannya. Hal ini sesuai dengan hasil penelitian Salam pada industri Koperasi Simpan Pinjam (KSP) yang menemukan bahwa semakin baik penerapan SOP dan SOM pada suatu koperasi maka semakin tinggi nilai rating KSP tersebut (Salam, 2008).

Dalam menunjang kelangsungan usahanya, BMT memerlukan dana yang cukup untuk membiayai seluruh kegiatan operasi dan pada akhirnya untuk mencapai salah satu tujuan usaha berupa perolehan keuntungan. Dalam operasionalnya, BMT memberikan pembiayaan kepada nasabah yang akan dibiayai atau mitra. Untuk melakukan pembiayaan berkelanjutan, BMT sebagai lembaga keuangan mikro mengalami keterbatasan dalam hal permodalan. Permodalan BMT dapat bersumber dari internal maupun eksternal. Sumbersumber permodalan tersebut membentuk faktor permodalan yang mempengaruhi sustainabilitas BMT. Pentingnya penguatan permodalan sebagaimana dipaparkan dalam penelitian Morshed tentang pengalaman sukses Grameen Bank sebagai pelaku keuangan mikro (Lamiya, 2005).

Sebagai lembaga keuangan, aktivitas utama BMT adalah memberikan layanan pembiayaan dan tabungan yang menguntungkan. Semakin besar kemampuan BMT menjangkau nasabah semakin besar pula skala ekonominya sehingga biaya operasionalnya bisa semakin efisien. BMT dengan kemampuan jangkauan pasar yang baik yang ditunjukkan dengan kemudahan akses penabung dan peminjam cenderung akan berkinerja baik. Dapat dikatakan bahwa semakin luas jangkauan pasar maka semakin banyak jumlah nasabah atau anggota yang dapat dilayani yang juga berarti semakin besar mobilisasi dana yang dapat dihimpun dan jumlah pinjaman yang dapat diberikan. Faktor jangkauan pasar dalam sisi teoritis dan praktis sebagai syarat utama dalam membentuk BMT yang sustainable. Secara deskriptif faktor jangkauan pasar menurut Robinson menegaskan kualitas layanan LKM dibentuk dari jangkauan 
pasar keuangan mikro mengacu pada sejumlah jasa keuangan skala kecil terutama pembiayaan dan tabungan. (Robinson,). Hal ini sejalan dengan hasil penelitian Siebel yang menekankan pada pemberian pelayanan yang berorientasi sebagai lembaga komersial untuk kelangsungan hidup LKM. (Siebel, 1999).

\section{METODE PENELITIAN}

Penelitian ini dilaksanakan di Propinsi Daerah Istimewa Yogyakarta. Alasan pemilihan wilayah ini didasarkan pada pertimbangan perkembangan BMT yang cukup pesat di wilayah ini dan memiliki karakteristik yang menarik dan beragam dari segi permasalahan-permasalahan yang dihadapi, sehingga dimungkinkan untuk mendapatkan data-data yang dibutuhkan sesuai dengan permasalahan yang diangkat dalam penelitian ini.

Penelitian ini termasuk explanatory research karena bermaksud menjelaskan hubungan kausal antar variabel melalui pengujian hipotesis. Populasi dalam penelitian ini adalah seluruh BMT yang beroperasi di wilayah Propinsi Daerah Istimewa Yogyakarta. Pengambilan sampel dalam penelitian ini dilakukan dengan cara purposive random sampling, yaitu teknik pengambilan sampel dimana peneliti mengambil sampel BMT secara acak dari populasi BMT yang sudah beroperasi minimal 3 tahun. Pengumpulan data pada penelitian ini dilakukan dengan metode survei yaitu menggunakan kuesioner yang menanyakan tingkat persepsi responden terhadap beberapa pernyataan yang berkaitan dengan variabel-variabel penelitian. Pengukuran variabel sustainabilitas BMT dalam penelitian ini juga menggunakan skala likert dan tidak menggunakan rasio-rasio keuangan karena adanya kesulitan untuk mengakses data-data keuangan BMT yang menjadi sampel penelitian.

Variabel yang akan diuji dalam penelitian ini terdiri atas variabel independen dan variabel dependen. Variabel independen yang digunakan dalam penelitian ini adalah adalah faktor-faktor eksternal dan internal yaitu aspek regulasi (X1), aspek pengawasan (X2), aspek infrastruktur (X3), aspek SDM (X4), aspek manajemen (X5), aspek permodalan (X6), aspek jangkaun pasar (X7) dan aspek inovasi produk (X8). Sedangkan variabel dependen adalah variabel sustainabilitas BMT (Y). 
Variabel-variabel tersebut merupakan konstruk (variabel laten yang tidak dapat diukur), sehingga setiap konstruk tersebut harus dijelaskan atau dibentuk dengan konstruk lainnya atau indikator yang terukur. Kesembilan variabel tersebut dijelaskan sebagai berikut:

a. Faktor Eksternal, yaitu :

1) Aspek Regulasi (X1)

Variabel regulasi diukur dengan kecukupan peraturan, penerapan prinsip kehati-hatian dan penerapan standar keuangan. Variabel ini merupakan variabel yang mengadopsi teori yang dikemukakan oleh Asian Development Bank (ADB) dalam melakukan kajian tentang pengembangan LKM. Hal yang menentukan sustainabilitas adalah penguatan tata hukum transaksi lembaga keuangan yang meliputi diantaranya regulasi dengan prinsip kehati-hatian. (ADB, 2000).

2) Aspek Pengawasan (X2)

Variabel pengawasan diukur dengan sistem pelaporan, efektifitas pelaksanaan pelaporan dan frekuensi pengawasan eksternal. Variabel ini merupakan variabel yang mengadopsi teori yang dikemukakan oleh Asian Development Bank (ADB) dalam melakukan kajian tentang pengembangan LKM. Hal yang menentukan sustainabilitas adalah penguatan tata hukum transaksi lembaga keuangan yang meliputi diantaranya pengawasan terhadap lembaga keuangan. (ADB, 2000).

3) Aspek Infrastruktur (X3)

Variabel infrastruktur diukur dengan keberadaan assosiasi, keberadaan lembaga rating, keberadaan jasa audit, keberadaan lembaga induk dan keberadaan lembaga penjaminan simpanan. Variabel ini merupakan variabel yang dikembangkan dari hasil penelitian kelembagaan terhadap lembaga keuangan mikro yang dilakukan oleh Hartarska tentang kinerja lembaga keuangan mikro yang menunjukkan bahwa dalam mekanisme pengelolaan dipengaruhi oleh faktor eksternal dan pemeringkatan atau jasa rating. (Hartarska, 2005). 
b. Faktor Internal, yaitu :

1) Aspek Sumber Daya Manusia (X4)

Variabel sumber daya manusia (SDM) dibentuk oleh indikator SDM berdasarkan pendidikan, SDM berdasarkan pengalaman, dan SDM berdasarkan pelatihan. Variabel ini merupakan variabel yang dikembangkan dari hasil penelitian Salam tentang Koperasi Simpan Pinjam (KSP), bahwa KSP dapat sustainable melalui peningkatan kapasitas lembaga KSP dengan perbaikan kondisi internal, diantaranya sumber daya manusia. (Salam, 2008).

2) Aspek Manajemen (X5)

Variabel manajemen dibentuk oleh indikator manajemen operasional berdasarkan Standar Operasional dan Prosedur (SOP), dan manajemen operasional berdasarkan Standar Operasional dan Manajemen (SOM). Variabel ini merupakan variabel yang mengadopsi teori yang dikemukakan oleh Salam bahwa Koperasi Simpan Pinjam (KSP) dapat menjadi LKM yang sustainable melalui peningkatan kapasitas lembaga KSP dengan perbaikan kondisi internal, diantaranya SOP dan SOM. (Salam, 2008).

3) Aspek Permodalan (X6)

Variabel yang memiliki hubungan dengan aspek permodalan adalah tabungan nasabah dan pinjaman yang diterima. Tabungan nasabah dibentuk oleh indikator tabungan nasabah berdasarkan total tabungan dan tabungan nasabah berdasarkan jumlah rekening. Pinjaman yang diterima dibentuk oleh indikator pinjaman yang diterima berdasarkan pinjaman komersil dan pinjaman yang diterima berdasarkan jumlah kreditur. Variabel ini merupakan variabel yang mengadopsi teori yang dikemukakan oleh Morshed tentang sumber-sumber permodalan yang membentuk faktor permodalan dan mempengaruhi sustainabilitas Grameen Bank sebagai pelaku keuangan mikro. (Lamiya, 2002).

4) Aspek Jangkauan Pasar (X7)

Variabel jangkauan pasar dibentuk oleh indikator jangkauan pasar berdasarkan jumlah account officer, jangkauan pasar berdasarkan jumlah pembiayaan, dan jangkauan pasar berdasarkan jumlah nasabah pembiayaan. 
Variabel ini merupakan variabel yang dikembangkan dari hasil penelitian yang dikemukakan oleh Martowijoyo bahwa diantara faktor yang mempengaruhi kinerja dan sustainabilitas lembaga keuangan pedesaan (LKP) adalah faktor jangkauan pasar. (Martowijoyo, 2001).

5) Aspek Inovasi Produk

Variabel inovasi produk dibentuk oleh indikator produk yang ditawarkan untuk usaha mikro. Variabel ini merupakan variabel yang dikembangkan dari hasil penelitian yang dikemukakan oleh Akhyar bahwa diantara faktor yang mempengaruhi kinerja BMT adalah produk yang ditawarkan. (Adnan, et. al., 2003).

\section{c. Sustainabilitas BMT (Y)}

Penilaian sustainabilitas BMT adalah dengan melihat aspek pertumbuhan total asset, aspek financing performance dan aspek profitabilitas BMT. Pertumbuhan aset total diukur dengan pertumbuhan pendapatan financial dan "Capital Edequacy Ratio", kualitas pembiayaan diukur dengan "Non Performing Financinag", "Financing to Deposit Ratio", dan kemampuan menghasilkan laba diukur dengan "Return On Average Assets" dan "Return On Average Equity". Indikator pada variabel ini merupakan adopsi dan modifikasi teori yang dikemukakan oleh Steinwand tentang model pengukuran pertumbuhan BPR yang berkesinambungan di Indonesia. (Steinwand, 2001).

Data yang berhasil diperoleh dalam penelitian ini berasal dari Baitul Maal wa Tamwil (BMT) yang beroperasi di Propinsi Daerah Istimewa Yogyakarta. Responden dalam penelitian ini adalah para pengelola BMT di wilayah Daerah Istimewa Yogyakarta yang bersedia menjadi narasumber untuk mengisi kuesioner. Dari 98 BMT yang memenuhi kriteria, hanya 69 BMT yang dapat diambil datanya untuk menjadi sampel penelitian. Selain itu dilakukan wawancara dengan beberapa pengurus assosiasi lembaga pembina BMT yang ada di Yogyakarta, antara lain Pusat Koperasi Syariah (Puskopsyah), Forum Mitra Ekonomi Syariah (Formes), dan MCI (Muamalat Center Indonesia). 
Metode analisis data dalam penelitian ini menggunakan multiple regression analysis. Penggunaan alat analisis multiple regression analysis berdasarkan pada pertimbangan bahwa penelitian yang dilakukan menekankan pada pengaruh antara beberapa variabel independen terhadap variabel dependen. Analisis regresi berganda dilakukan untuk menetapkan ada atau tidaknya pengaruh antara sustainabilitas BMT dengan variabelvariabel yang mempengaruhinya.

\section{HASIL DAN PEMBAHASAN}

Hasil analisis regresi yang dilakukan pada dua model regresi adalah sebagai berikut:

a) Model Regresi Pertama

Model regresi pertama dilakukan untuk menganalisis pengaruh variabel-variabel penyusun faktor eksternal, yaitu Regulasi (X1), Pengawasan (X2) dan Infrastruktur (X3) terhadap Sustainabilitas BMT (Y). Hasil analisis regresi model ini dipaparkan dalam tabel berikut:

Tabel 1: Model Summary Model I

\begin{tabular}{|c|c|c|c|}
\hline $\mathbf{R}$ & R Square & $\begin{array}{c}\text { Adjusted } \\
\text { R Square }\end{array}$ & $\begin{array}{c}\text { Std. Error } \\
\text { of the } \\
\text { Estimate }\end{array}$ \\
\hline 0,687 & 0,472 & 0,448 & 3,583 \\
\hline
\end{tabular}

Berdasarkan tabel diatas, diperoleh nilai $R$ square sebesar 0,472. Berdasarkan nilai tersebut maka dapat diambil kesimpulan bahwa besaran koefisien determinasi dalam model regresi ini adalah $47,20 \%$ yang berarti bahwa variabel sustainabilitas BMT dalam penelitian ini 47,20\% nya dijelaskan oleh faktor eksternal yaitu variabel regulasi, pengawasan dan infrastruktur. Sedangkan $52,80 \%$ sisanya dijelaskan oleh faktor-faktor lain di luar ketiga variabel tersebut. 
Selanjutnya, pengujian pengaruh masing-masing variabel dilakukan dengan didasarkan pada paparan dalam tabel berikut ini :

Tabel 2: Coefficient Model I

\begin{tabular}{|l|c|c|c|c|}
\hline \multicolumn{1}{|c|}{ Variabel } & $\begin{array}{c}\text { Koefisien } \\
\text { Regresi }\end{array}$ & Beta & T & $\begin{array}{c}\text { Nilai } \\
\text { Sig. }\end{array}$ \\
\hline Constant & $-10,793$ & & - & 0,012 \\
\hline Regulasi (X1) & 0,659 & 0,246 & 2,425 & 0,018 \\
\hline $\begin{array}{l}\text { Pengawasan } \\
(X 2)\end{array}$ & 0,812 & 0,276 & 2,598 & 0,012 \\
\hline $\begin{array}{l}\text { Infrastruktur } \\
(X 3)\end{array}$ & 0,634 & 0,385 & 3,945 & 0,000 \\
\hline
\end{tabular}

Hasil analisis tabel di atas menunjukkan nilai signifikansi ketiga variabel penyusun faktor eksternal berada jauh di bawah 0,05. Hal ini berarti bahwa variabel-variabel regulasi, pengawasan dan infrastruktur memberikan pengaruh positif yang signifikan terhadap sustainabilitas BMT. Semakin tinggi faktor eksternal maka semakin tinggi pula sustainabilitas BMT. Artinya semakin baik regulasi, pengawasan dan infrastruktur yang ada akan memberikan pengaruh positif terhadap sustainabilitas BMT.

Berdasarkan tabel di atas, selanjutnya dapat disusun persamaan model regresi pertama sebagai berikut:

$$
\begin{gathered}
\mathrm{Y}=-10,793+0,659(\mathrm{X} 1)+0,812(\mathrm{X} 2)+0,634 \\
(\mathrm{X} 3)+\varepsilon_{1}
\end{gathered}
$$

b) Model Regresi Kedua

Model regresi kedua dilakukan untuk menganalisis pengaruh variabel-variabel penyusun faktor internal, yaitu SDM (X4), Manajemen (X5), Permodalan (X6), Jangkauan Pasar (X7) dan Inovasi Produk (X8) terhadap Sustainabilitas BMT (Y). Hasil analisis regresi model ini dipaparkan dalam tabel berikut : 
Tabel 3: Model Summary Model II

\begin{tabular}{|c|c|c|c|}
\hline $\mathbf{R}$ & R Square & $\begin{array}{c}\text { Adjusted } \\
\text { R Square }\end{array}$ & $\begin{array}{c}\text { Std. Error of } \\
\text { the Estimate }\end{array}$ \\
\hline 0,717 & 0,514 & 0,476 & 3,489 \\
\hline
\end{tabular}

Berdasarkan tabel di atas, diperoleh nilai $R$ square sebesar 0,514. Berdasarkan nilai tersebut maka dapat diambil kesimpulan bahwa besaran koefisien determinasi dalam model regresi ini adalah $51,40 \%$ yang berarti bahwa variabel sustainabilitas BMT dalam penelitian ini $51,40 \%$ nya dijelaskan oleh faktor internal yaitu variabel SDM, Manajemen, Permodalan, Jangkauan Pasar dan Inovasi Produk. Sedangkan 48,60\% sisanya dijelaskan oleh faktorfaktor lain di luar kelima variabel tersebut. Selanjutnya, pengujian pengaruh masing-masing variabel dilakukan dengan didasarkan pada paparan dalam tabel berikut ini :

Tabel 4: Coefficient Model II

\begin{tabular}{|l|c|c|c|c|}
\hline \multicolumn{1}{|c|}{ Variabel } & $\begin{array}{c}\text { Koefisien } \\
\text { Regresi }\end{array}$ & Beta & T & $\begin{array}{c}\text { Nilai } \\
\text { Sig. }\end{array}$ \\
\hline Constant & $-0,146$ & & $-0,054$ & 0,957 \\
\hline SDM (X4) & 0,689 & 0,329 & 3,363 & 0,001 \\
\hline Manajemen (X5) & 0,569 & 0,181 & 1,852 & 0,069 \\
\hline Permodalan (X6) & 0,543 & 0,373 & 3,435 & 0,001 \\
\hline $\begin{array}{l}\text { Jangkauan Pasar } \\
\text { (X7) }\end{array}$ & 0,083 & 0,062 & 0,588 & 0,559 \\
\hline $\begin{array}{l}\text { Inovasi Produk } \\
(X 8)\end{array}$ & 0,204 & 0,055 & 0,582 & 0,563 \\
\hline
\end{tabular}

Hasil analisis tabel di atas menunjukkan dari kelima variabel penyusun faktor internal BMT, hanya terdapat dua variabel yang memiliki nilai signifikansi di bawah 0,05 yaitu variabel sumber daya manusia dan permodalan. Hal ini berarti bahwa variabel sumber daya manusia dan permodalan suatu BMT memberikan pengaruh positif yang signifikan terhadap Sustainabilitas BMT. Sedangkan ketiga variabel yang lain, yaitu manajemen, jangkauan pasar dan inovasi produk suatu BMT tidak memberikan pengaruh yang 
signifikan terhadap Sustainabilitas BMT. Berdasarkan tabel di atas, selanjutnya dapat disusun persamaan model regresi kedua sebagai berikut:

$$
\begin{aligned}
& Y=-0,146+0,689(X 4)+0,569(X 5)+0,543(X 6)+0,083 \\
& (X 7)+0,204(X 8)+\varepsilon_{1}
\end{aligned}
$$

Berdasarkan hasil analisis data yang telah dijelaskan menunjukkan bahwa faktor-faktor eksternal dan internal yang ditentukan memiliki pengaruh terhadap sustainabilitas BMT adalah aspek regulasi, aspek pengawasan, aspek infrastruktur, aspek sumber daya manusia, dan aspek permodalan.

\section{1) Aspek Regulasi}

Regulasi merupakan faktor yang penting karena operasional BMT akan dikelola sesuai dengan aturan-aturan yang ditetapkan. Berdasarkan uji regresi yang telah dilakukan dalam penelitian ini diketahui bahwa aspek regulasi yang dibentuk oleh indikator kecukupan peraturan dan penerapan prinsip kehati-hatian serta penerapan standar keuangan terbukti berpengaruh positif dan signifikan terhadap sustainabilitas BMT. Temuan ini didukung pula oleh penelitian Staschen yang mengungkapkan bahwa terdapat dua instrumen regulasi, yaitu perlindungan dan pencegahan. Instrumen perlindungan dimaksudkan untuk memberi perlindungan bagi nasabah dan lembaga keuangan mikro dari kemungkinan bangkrut. Sedangkan instrumen pencegahan dimaksudkan untuk mencegah agar lembaga keuangan mikro tidak mengalami kebangkrutan. (Staschen, 1994).

Regulasi merupakan salah satu infrastruktur yang sangat mempengaruhi kinerja BMT. Regulasi bukan hanya merupakan faktor eksternal bagi BMT tetapi juga untuk semua lembaga dalam industri LKM termasuk BMT. Kedua instrumen tersebut hanya dapat dijalankan secara optimal apabila didukung oleh penyampaian laporan secara teratur, pembatasan lingkup usaha, penetapan tingkat kesehatan, rasio kecukupan modal yang memadai dan sebagainya. Ketentuan Bank Indonesia tentang BPR menyatakan bahwa regulasi yang efektif tercermin dari kecukupan dan ketepatan penerapan peraturan-peraturan serta seberapa jauh suatu 
lembaga menerapkan kehati-hatian dalam kegiatan usahanya. (Bank Indonesia, 2006).

Namun yang perlu diperhatikan adalah penerapan instrumen tersebut harus sesuai dengan karakteristik lembaga keuangan sehingga regulasi yang ditetapkan bisa efektif. Dalam hal ini BMT sebagai lembaga keuangan mikro yang berbasis syariah harus membuat peraturan-peraturan pelaksanaan sendiri dan prosedur operasi yang baku. BMT justru harus lebih ketat dalam mengikuti dan mematuhi prinsip tersebut karena dalam hal pengelolaan kegiatan usaha terdapat kesamaan resiko dengan perbankan. Disamping itu, regulasi diperlukan untuk melindungi para penabung kecil dalam hal menghindari ketidakmampuan BMT membayar simpanan nasabah bila terjadi penarikan dana besar-besaran akibat menurunnya kepercayaan nasabah. Oleh karena itu, regulasi harus diterapkan secara efektif dalam industri LKM, khususnya BMT.

2) Aspek Pengawasan

Pengawasan yang efektif merupakan salah satu alat untuk mendeteksi permasalahan secara dini (early warning system). Indikator-indikator yang membentuk pengawasan yang efektif dalam penelitian ini adalah sistem pelaporan, efektivitas pelaksanaan laporan dan pengawasan eksternal oleh Dewan Pengawas Syariah (DPS). Berdasarkan uji regresi yang telah dilakukan dalam penelitian ini diketahui bahwa aspek pengawasan terbukti berpengaruh positif dan signifikan terhadap sustainabilitas BMT.

Pengawasan lembaga BMT membutuhkan adanya pengawas dengan kompetensi khusus karena aspek-aspek yang diawasi sangat spesifik dan rinci. Hal ini sangat penting agar BMT dapat mematuhi aturan-aturan syariah yang berlaku. Pengawasan yang efektif merupakan alat kontrol bagi BMT untuk beroperasi secara sehat sehingga dapat berkembang secara wajar serta memperoleh kepercayaan masyarakat. Salah satu hal yang paling penting dalam kaitannya dengan pengawasan DPS adalah sumber daya manusia (SDM) ditingkat Dewan Pengawas Syariah. Di samping itu, belum adanya standar pembinaan dan pengawasan yang baku untuk BMT dan ada beberapa BMT 
yang belum mempunyai lembaga pengawas, secara tidak langsung telah ikut menghambat perkembangan BMT.

Peran utama DPS adalah mengawasi jalannya operasional lembaga keuangan sehari-hari agar selalu sesuai dengan ketentuan-ketentuan syariah. Hal ini dimaksudkan agar tidak terjadi kerancuan dalam pelaksanaan peraturannya, sehingga menimbulkan keresahan masyarakat ataupun hal-hal yang tidak diinginkan. Tugas lain dari DPS adalah meneliti dan membuat rekomendasi produk baru dari lembaga keuangan yang diawasi. Dengan demikian, DPS bertindak sebagai penyaring pertama sebelum suatu produk diteliti kembali dan difatwakan oleh DSN. Oleh karena itu setiap BMT harus memiliki DPS.

3) Aspek Infrastruktur

Infrastruktur merupakan faktor yang penting bagi lembaga BMT. Berdasarkan uji regresi yang telah dilakukan dalam penelitian ini diketahui bahwa aspek infrastruktur dibentuk oleh indikator-indikator yang terdiri dari peran assosiasi, lembaga rating, jasa audit, lembaga induk dan lembaga penjamin simpanan terbukti berpengaruh positif dan signifikan terhadap sustainabilitas BMT.

Keberadaan assosiasi berperan dalam pelatihan, konsultasi serta upaya akses dana dari lembaga keuangan kepada anggota. Mengenai keberadaan lembaga rating dan jasa audit independen bagi BMT sangat diperlukan namun masih perlu sosialisasi lebih lanjut untuk membentuk persepsi yang benar mengenai palaksanaan audit dan rating. Jasa audit dan rating diperlukan sebagai penilai kinerja keuangan independen sehingga lebih obyektif dan transparan. Sedangkan lembaga induk dan lembaga penjamin simpanan (LPS) bagi nasabah BMT sebagai lembaga pendukung sangat diperlukan, namun LPS belum dibentuk. Keberadaan LPS pada dasarnya sangat dibutuhkan untuk mendukung untuk perkuatan sumber dana BMT. Namun untuk saat ini masih belum dimungkinkan adanya lembaga LPS nasabah BMT karena belum terpenuhinya prasyarat terbentuknya industri BMT yang terstandardisasi dan heterogen.

Sejalan dengan pengembangan ekonomi mikro dan mencermati semakin banyaknya LKM di Indonesia, termasuk 
telah dikembangkannya sistem ekonomi syariah sehingga lahir LKM dengan sistem syariah seperti BMT, di mana masih tergolong lembaga informal. Oleh karena itu, untuk keperluan pengembangan kelembagaan agar menjadi lembaga keuangan yang baik dan sehat, perlu didukung dengan tersedianya infrastruktur kelembagaan yang memadai. Minimal kelembagaan tersebut mencakup adanya jaringan yang kuat, baik antar BMT maupun antara BMT dengan lembaga keuangan lain.

4) Aspek Sumber Daya Manusia

Kualitas Sumber Daya Manusia (SDM) pengelola BMT dapat dilihat dari tingkat pendidikan formal pengelola dan frekuensi pelatihan yang terkait dengan tugas serta pengalaman pengelola. Berdasarkan uji regresi yang telah dilakukan dalam penelitian ini diketahui bahwa aspek sumber daya manusia terbukti berpengaruh positif dan signifikan terhadap sustainabilitas BMT. Hal ini sejalan dengan hasil penelitian Akhyar yang menyatakan bahwa tingkat pendidikan para pengurus BMT merupakan faktor nyata yang menentukan kemampuan bertahan (sustainability) BMT secara keseluruhan. (Adnan, et. al., 2003).

Tingkat pendidikan dan pengetahuan yang memadai dikalangan pengurus juga merupakan salah satu faktor yang menjadi kunci keberhasilan Pusat Inkubasi Bina Usaha Kecil (Pinbuk) dalam pengembangan BMT, dimana setiap pendirian BMT harus didampingi oleh seorang sarjana yang telah mengikuti pelatihan community leadership development. Bila dilihat dari segi rata-rata pengalaman pengurus dan manajemen BMT, menunjukkan bahwa BMT pada umumnya dikelola oleh SDM yang telah berpengalaman. Dari rekonfirmasi terhadap responden disimpulkan bahwa setiap BMT memiliki kekhasan dan pengelola yang berhasil pada umumnya mampu memahami karakteristik masing-masing BMT serta mampu beradaptasi dengan anggotanya. Hal ini tercermin dari keikutsertaan pengelola BMT dalam berbagai pelatihan yang diselenggarakan oleh lembaganya sendiri ataupun oleh pihak assosiasi atau instansi terkait. Dukungan terhadap pengembangan SDM relatif cukup mendapat porsi yang besar 
dalam program peningkatan kapasitas SDM. Pelatihanpelatihan tersebut beragam mulai dari pelatihan mental/ spiritual yang diarahkan guna membangun pemikiran yang kuat dan kreatif, hingga sesi-sesi yang dirancang untuk mengembangkan pengetahuan dan ketrampilan manajemen profesional.

\section{5) Aspek Permodalan}

Permodalan BMT yang dimaksud dalam hal ini adalah dana dari pendiri lembaga keuangan tersebut yang berasal dari pemilik BMT maupun modal BMT yang diinvestasikan pada nasabah dan modal nasabah yang diinvestasikan pada BMT. Berdasarkan uji regresi yang telah dilakukan dalam penelitian ini diketahui bahwa aspek permodalan yang diukur dengan simpanan anggota berdasarkan jumlah total nilai simpanan, simpanan anggota berdasarkan jumlah rekening simpanan, pinjaman diterima berdasarkan jumlah total nilai pinjaman yang diterima dan pinjaman yang diterima berdasarkan jumlah kreditur pemberi pinjaman terbukti berpengaruh positif dan signifikan terhadap sustainabilitas BMT.

Kombinasi antara jumlah total nilai simpanan dengan jumlah rekening simpanan digunakan untuk menunjukkan adanya penyebaran resiko likuiditas mengikuti hukum probabilitas angka, yaitu semakin banyak jumlah rekening atau nasabah maka semakin kecil pula kemungkinan nasabah tersebut menarik simpanannya dalam waktu bersamaan. Nilai simpanan anggota yang semakin besar dengan jumlah rekening simpanan semakin besar menunjukkan BMT memiliki sumber dana dari simpanan anggota dengan tingkat resiko likuiditas yang relatif kecil. Dengan demikian, probabilitas terjadinya rush relatif kecil. Sedangkan kombinasi antara indikator jumlah nilai pinjaman yang diterima dengan jumlah kreditur pemberi pinjaman menunjukkan tingkat kepercayaan kreditur sebagai penyedia sumber permodalan kepada BMT. Semakin banyak kreditur yang memberikan kepercayaan kepada BMT melalui pemberian pinjaman maka BMT semakin memiliki keleluasaan sumber pendanaan. 
Permodalan dan sumber pendanaan BMT umumnya memiliki modal yang relatif kecil dan sulit untuk menambah modal apabila diperlukan. Kemampuan BMT dalam menghimpun dana masih sangat terbatas, padahal jumlah nasabah pembiayaan yang harus dilayani cukup besar. Bagi BMT yang mempunyai total aset kecil, akumulasi kebutuhan dana masyarakat belum bisa dipenuhi secara maksimal. Hal ini menjadikan nilai pembiayaan yang diberikan BMT belum cukup memadai untuk modal usaha masyarakat. Hal ini berarti ketersediaan dana yang terbatas pada sebagian besar BMT akan mempersulit pengembangan usaha. Oleh karena itu, BMT membutuhkan modal minimum yang besar dan memadai agar BMT dapat menutupi biaya operasionalnya.

\section{PENUTUP}

Aspek-aspek dari faktor-faktor eksternal dan internal yang ditentukan memiliki pengaruh terhadap sustainabilitas BMT adalah aspek regulasi, pengawasan, infrastruktur, sumber daya manusia, dan permodalan. Aspek-aspek tersebut dapat dijadikan sebagai tuntunan untuk meningkatkan kinerja BMT menuju sustainabilitas lembaga keuangan mikro berbasis syariah. Temuan ini dapat dijadikan sebagai patokan bagi pengembangan BMT sebagai sebuah sistem intermediasi keuangan berbasis syari'ah di level mikro. Kendala-kendala yang dihadapi BMT, baik yang bersifat internal maupun yang eksternal, perlu segera diselesaikan agar sustainabilitas BMT tetap terjaga.

Beberapa faktor yang menyebabkan perkembangan BMT tidak terlepas dari pengaruh faktor eksternal maupun faktor internal BMT itu sendiri yang menjadikan institusi BMT tetap eksis. Oleh karena itu, untuk penguatan BMT sebagai lembaga keuangan mikro syariah (LKMS), diperlukan dua sisi. Dari sisi eksternal berupa peranan para stakeholder dalam hal ini pemerintah, perusahaan, perbankan syariah dan masyarakat dalam upaya mendukung iklim kondusif dan menyiapkan infrastruktur yang memadai bagi tumbuh kembangnya BMT di Indonesia, sedangkan di sisi internal berupa penguatan permodalan dan kelembagaan sehingga BMT dapat tumbuh 
Iqtishadia, Vol. 9, No. 2, 2016

menjadi organisasi yang mapan dan kredibel untuk meningkatkan kontribusi BMT dalam memberikan alternatif permodalan bagi usaha mikro di seluruh Indonesia. 


\section{DAFTAR PUSTAKA}

Asian Development Bank (ADB). (2000). Finance for the Poor, Microfinance Development Strategy. ADB. Manila.

Adnan, Muhammad Akhyar dkk. (2003). Study on Factors Influencing Performance of the Best Baitul Maal Wat Tamwils [BMTS] in Indonesia. IQTISAD Journal of Islamic Economics. 4(1).

Amaliah, Euis. (2009). Keadilan Distributif dalam Ekonomi Islam. Perkuatan Peran LKM dan UKM di Indonesia. RajaGarfindo Persada. Jakarta.

Arikunto, Suharsono. (2002). Prosedur Penelitian: Suatu Pendekatan Praktek. Aneka Cipta. Jakarta.

Woller, G. Dunford, C. \& Warner. (1991). Where to Microfinance. International of Economic Development.

Bank Indonesia. (2006). Cetak Biru Bank Perkreditan Rakyat. Bank Indonesia. Jakarta.

Campion, A. (2002). Challenges to Microfinance Commercialization. Journal of Microfinance, 4.

Chaves, Rodrigo. dan Claudio Gonzales-Vega. (1996). The Design of Successful Rural Financial Intermediaries: Evidence from Indonesia. World Development, 24.

Hartarska, Valentina. (2004). Governance and Performance of Microfinance Institutions in Central and Eastern Europe and the Newly Independent States, Aurburn University.

Jiwani, J. dan Husain, J. (2011). Strategic Impact of Incentive Programs for Loan Officers of Micro-Finance Institutions. Journal of American Academy of Business. Cambridge, 17.

Lamiya, Morshed. (2002). To Expand Microfinance for Poverty Allevation, What is the Main Constraint? Capital or Capacity Building?: Grameen Trust Experience. Grameen Trust on CGAP. http://www.grameen.com/dialogue/dialogue49/ special feature01.html, diakses tanggal 1 Desember 2015.

Martowijoyo, Sumantoro. (2001). Dampak Pemberlakuan Sistem Bank Perkreditan Rakyat Terhadap Kinerja Lembaga Keuangan Pedesaan. Desertasi Doktor Universitas Gadjah Mada, Yogyakarta. 
Murdock, Jonathan. (2000). Financial Performance and Outrech: A Global Analysis of Leading Microbanks. World Development.

Meyer, R. L. (2002). Track Record of Financial Institutions in Assisting the Poor in Asia. ADB Institute Research Paper, 49.

Promotion of Small Financial Institution (ProFi). (2005). Guiding Principles on Regulation and Supervision of Microfinance. Microfinance Consensus Guidelines.

Robinson, Marguirete. (2002). The Microfinance Revolution: Lesson from Indonesia. The World Bank. Washington DC.

Sakai, Minako dan Kacung Marijan. (2008). Mendayagunakan Pembiayaan Mikro Islami. Australia Indonesia Governance Research Partnership Crawford School of Economics and Government ANU College of Asia and the Pacific. The Australian National University.

Salam, Abdul. (2008). Sustainabilitas Lembaga Keuangan Mikro Koperasi Simpan Pinjam, Sekolah Pascasarjana UGM. Yogyakarta.

Sekaran, Uma. (2006). Metodologi Penelitian Bisnis. Buku 2. edisi 4. Terj. Kwn Men Yon, Salemba Empat. Jakarta.

Staschen, Stefan. (1994). Regulation and Supervision of Microfinance Institutions: state of Knowledge. GTZ. Eschborn.

Steinwand, Dirk. (2001). The Alchemy of Microfinance: The Evolution of the Indonesian People's Credit Banks (BPR) from 1895 to 1999 and a Contemporary Analysis. VWF. Berlin.

Sugiyono. (2009). Statistika Untuk Penelitian. Alfabeta. Bandung.

The Asia Fondation. (2003). Microfinance Service in Indonesia: Survey of Institutions in 6 Provinces. The Asia Foundation. Jakarta. 